\title{
EDUCAÇÃO E IMUNIDADES TRIBUTÁRIAS
}

\author{
IVES GANDRA DA SILVA MARTINS*
}

Tem-se discutido, nos últimos tempos, a conformação das imunidades para instituições de educação e assistência social, razão pela qual este estudo será dedicado à minha pessoal inteligência do instituto constitucional e sua implementação legislativa.

Tecerei variadas considerações, objetivando demonstrar que o artigo 150, inciso VI, letra "c", ao falar de lei referiu-se à lei complementar e que tal lei complementar não pode criar restrições que não foram perfiladas na Carta Maior.

A primeira delas diz respeito ao veículo legislativo adequado a explicitar a imunidade constitucional de impostos e contribuições, referentes ao $\S 7^{\circ}$ do artigo 195 da Constituição Federal, das entidades de educação e assistência social.

O Tribunal Federal de Recursos, antes da Constituição de 1988, em decisão do pleno, em cujo recurso fiz a sustentação oral, decidiu que a lei para definir as imunidades das instituições fechadas de previdência privada teria que ser necessariamente complementar ${ }^{1}$.

$\mathrm{O}$ argumento essencial residia no fato de que, estando a imunidade entre as limitações constitucionais ao poder de tributar, a Constituição passada definia como sendo função da lei complementar estabelecer tais limitações, por força do artigo $18, \S 1^{\circ}$, da E.C. n. $1 / 69$, assim redigido:

* Professor Emérito da Universidade Mackenzie, em cuja Faculdade de Direito foi Titular de Direito Econômico e de Direito Constitucional e Presidente do Centro de Extensão Universitária. 1 Pontes de Miranda ensina sobre o direito pretérito que: "Mesmo quando o art. $18, \S 1^{\circ}$, diz que pode constar de lei complementar a regulação das 'limitações constitucionais do poder tributário', com isso não abriu portas a limitações pela União no tocante à tributação: o que se permitiu foi regularem-se as 'limitações constitucionais do poder de tributar', isto é, limitações que constem da Constituição, e não estabelecerem-se limitações extraconstitucionais. Regular limitação constitucional não é criar limitações, porque, aí, seria o legislador, e não o Congresso Constituinte, que limitaria" (grifos meus) (Comentários à Constituiçâa de 1967 c/a emenda n. 1 de 1969, tomo II, Ed. Forense, p. 384). 
"1․ Lei complementar estabelecerá normas gerais de direito tributário, disporá sobre os conflitos de competência nessa matéria entre a União, os Estados, o Distrito Federal e os Municípios, e regulará as limitações constitucionais do poder de tributar" (grifos meus).

E se compreende a finalidade dessa disposição, visto que, se a regulação ao poder de tributar devesse necessariamente surgir da lei complementar explicitadora da Constituição, não se poderia admitir que leis ordinárias da União, de todos os Estados e de todos os Municípios definissem, no âmbito de suas competências impositivas, quais seriam as condições mediante as quais as imunidades poderiam ser usufruídas pelas instituições elencadas na lei suprema².

O Ministro Moreira Alves, em conferência no XXIV Simpósio Nacional de Direito Tributário, claramente mostrou que nem mesmo cabe à lei complementar definir as condições ou requisitos para tanto, mas apenas explicitá-las, ao interpretar voto de Soares Munhoz dizendo:

"Mas o Ministro Soares Muñoz não decidiu isso. Ele não estava tratando, aqui, de saber se era lei complementar ou não era lei complementar. Tanto que ele disse o seguinte: "Esse decreto-lei, anterior à Constituição Federal em vigor, não pode, no particular, ser aplicado. Porque ele impõe uma restrição à imunidade, a qual não se confunde com isenção; uma restrição que não está no texto constitucional". Isso significava dizer o quê? Dizer: "Nem lei complementar, nem lei nenhuma, pode impor uma restrição a uma imunidade que decorre da Constituição" (grifos meus) ${ }^{3}$.

Como se percebe - o princípio é elementar e de conhecimento de qualquer estudante de Direito - é a lei ordinária que se subordina à Constituição e não a Constituição à lei ordinária, demonstrando, o Ministro Moreira Alves - até com certa irritação —, que não se pode aceitar a interpretação conivente de certas autoridades, de que a lei ordinária tudo pode, inclusive definir quais requisitos a que as entidades imunes devem subordinar-se, visto que se pudesse, à nitidez, sujeita estaria a Constituição aos humores do legislador de cada uma das entidades federativas, podendo elevar e reduzir os requisitos, conforme suas conveniências ${ }^{4}$.

2 É ainda Pontes de Miranda que esclarece a função da lei complementar: "Lei complementar pode regular limitações constitucionais; não criar limitações. Lei que cria limitações não está a regular limitações constitucionais, está a limitar. As limitações seriam suas, e a Constituição de 1967 não as permitiu" (grifos meus) (ob. cit., p. 385).

3 Pesquisas Tributárias - Nova Série n. 5, Processo Administrativo Tributário, ed. Centro de Extensão Universitária/Ed. Revista dos Tribunais, $2^{a}$ ed., 2001, p. 31.

4 "E, a meu ver, está absolutamente correto. Porque não é possível se admitir que uma lei complementar, ainda que a Constituição diga que ela pode regular limitações à competência tributária, possa aumentar restrições a essa competência. Ela pode é regulamentar. - Se é que há o que regulamentar, em matéria de imunidade, no sentido de ampliá-la ou reduzi-la. Porque 
Na referida decisão, o Tribunal Federal de Recursos declarou que:

“Argüição de Inconstitucionalidade na Apelação Cível n. 101.394-Paraná - Registro n. 7174675.

Rel. Sr. Min. Ilmar Galvão - Remetente: Juízo Federal da $3^{a}$ Vara Apelante: União Federal - Apelada: Fundação C. de Previdência e Assistência Social - Suscitante do Incidente: Egrégia $4^{a}$ Turma do TFR Advs.: Dr. Agnaldo Mendes Bezerra e Ives Gandra da Silva Martins.

Ementa: Tributário. Entidades privadas de previdência social fechada. Instituições complementares do sistema oficial de previdência e assistência social (art. 35 da Lei n. 6.435/77).

Inconstitucionalidade dos $\S \S 1^{\circ}$ e $2^{\circ}$, do art. $6^{\circ}$, do DL. 2.065/83, que consideraram sujeitos ao imposto de renda os rendimentos de capital auferidos pelos entes da espécie. A assistência social, hodiernamente, não se resume à caridade pública, podendo também realizar-se por meio da previdência, que corresponde à assistência preventiva, destinada aos impossibilitados de continuarem trabalhando e à família dos que sucumbem.

As entidades em tela, por isso, são beneficiárias da imunidade prevista no art. 19, 111, "c", da CF, regulamentado pelo art. $9^{\circ}$, IV, "c", c/c o art.14, do CTN, que não condiciona o beneficio à gratuidade dos serviços prestados, nem exige que sejam acessíveis a todas as pessoas indistintamente (RE 70.834-RS, RE 89.012-SP, RE 108.796-SP e RE 115.97O-RS).

Argüição procedente.

Acórdão: Vistos e relatados estes autos em que são partes as acima indicadas, Decide o TFR, em Seção Plena, por maioria, declarar a inconstitucionalidade $\operatorname{dos} \S \S 1^{\circ}$ e $2^{\circ}$, do art. $6^{\circ}$, do DL $2.065 / 83$, na forma do relatório e notas taquigráficas constantes dos autos, que ficam fazendo parte integrante do presente julgado.

Custas, como de lei.

Brasília, DF, 30/6/88 (data do julgamento) (DJ, 31 out. 1988), ${ }^{5}$

lembrando-se que, na Carta atual, não mais um único artigo cuida das limitações constitucionais ao poder de tributar, mas toda uma seção (II), do Capítulo I, do Título VI, assim denominada: "Das limitações do Poder de Tributar".

E é de se lembrar que o inciso II do artigo 146 da Constituição Federal declara que:

isso decorre estritamente da Constituição. Quando se diz, por exemplo, 'para atender às suas finalidades essenciais', não é a lei que vai dizer quais são as finalidades essenciais. Quem vai dizer quais são as finalidades essenciais é a interpretação da própria Constituição. Porque Constituição nāo se interpreta por lei infraconstitucional, mas a lei infraconstitucional é que se interpreta pela Constituição" (grifos meus) (ob. cit., p. 31/32).

5 Comentários à Constituição do Brasil, $6^{\circ}$ vol., tomo I, Ed. Saraiva, 1990, p. 184. 
"Art. 146 Cabe à lei complementar: ... II. regular as limitações constitucionais ao poder de tributar",

estando, o inciso VI, letra "c", do art. 150, dedicado às limitações constitucionais ao poder de tributar, assim redigido:

“Art. 150 Sem prejuízo de outras garantias asseguradas ao contribuinte, é vedado à União, aos Estados, ao Distrito Federal e aos Municípios: ... VI. instituir impostos sobre: .... c) patrimônio, renda ou serviços dos partidos políticos, inclusive suas fundações, das entidades sindicais dos trabalhadores, das instituições de educação e de assistência social, sem fins lucrativos, atendidos os requisitos da lei".

A interpretação sistemática do art. 146, inc. II, com o artigo 150, inc. VI, letra "c", constante da seção das limitações constitucionais ao poder de tributar, não admite, portanto, que possa, cada legislador ordinário com competência impositiva de impostos - vale dizer, da União, dos 26 Estados, do Distrito Federal e de 5.500 municípios - definir quais seriam as condições, de acordo com seus "interesses" e "necessidades", para que tais entidades pudessem gozar da imunidade.

Poderíamos chegar ao absurdo de ter um legislador municipal determinando que uma instituição de assistência social não seria imune de IPTU, com base em requisitos pelo burgo criados e a União considerá-la imune, por força de requisitos conformados em legislação federal.

Exatamente para impedir que 5.500 entidades federativas pudessem produzir 5.500 leis ordinárias definidoras dos requisitos necessários para a concessão da imunidade foi que, sabiamente, o constituinte exigiu que lei complementar (inc. II do art. 146) regulasse as limitações constitucionais ao poder de tributar das quais a imunidade é uma delas.

O Ministro Moreira Alves, na já mencionada ADIN n. 2028, prestou a devida relevância à reserva da lei complementar, no que foi acompanhado por outros nove ministros. Eis o trecho de seu voto:

"É certo, porém, que há forte corrente doutrinária que entende que, sendo a imunidade uma limitação constitucional ao poder de tributar, embora o §

6 Escrevi: "O segundo inciso faz menção às limitações ao poder de tributar expostas na Constituição, reproduzindo o discurso antérior. Apenas, no Texto anterior, a limitação era 'do poder' e não, como no Texto atual, 'ao poder' de tributar.

Se a limitação é ao poder de tributar, tal limitação refere-se à faculdade que o poder tributante tem de tributar. Se a limitação fosse do poder de tributar, tal limitação referir-se-ia ao próprio poder tributante. A configuração gramatical, todavia, não altera o produto final da limitação, que impõe restrições, de rigor, à faculdade e ao próprio poder, por decorrência.

Tais limitações, todavia, estão no Texto Constitucional, sendo pequeno o âmbito de ação outorgada ao legislador complementar. O pequeno campo de atuação do passado continua no presente" (Comentários à Constituição do Brasil, $6^{\circ}$ vol., tomo I, Ed. Saraiva, $2^{\text {a }}$ ed., 2001, p. 88). 
$7^{\circ}$ do art. 195 só se refira a "lei" sem qualificá-la como complementar e o mesmo ocorre quanto ao art. 150, VI, "c", da Carta Magna -, essa expressão, ao invés de ser entendida como exceção ao princípio geral que se encontra no art. 146, II ("Cabe à lei complementar: ... II. regular as limitações constitucionais ao poder de tributar"), deve ser interpretada em conjugação com esse princípio para se exigir lei complementar para o estabelecimento dos requisitos a ser observados pelas entidades em causa"?

Tal matéria só não decidiu, na ocasião, porque havia outras inconstitucionalidades evidentes na Lei 9732/99. E se tivesse que, no processo cautelar, declarar a necessidade de lei complementar, isso implicaria declarar, também, a inconstitucionalidade da Lei 8212/91, que não fora objeto da ação ${ }^{8}$.

Considerou, todavia, de tal relevância o argumento e a poderosíssima corrente doutrinária - é a esmagadora maioria dos tributaristas - que preferiu transferir a discussão da tese para a decisão definitiva, ainda não ocorrida.

S. Exa., todavia, proferiu a palestra inaugural no XXIV Simpósio Nacional de Direito Tributário do CEU, em que se discutiu o tema. Após suas considerações para aproximadamente 200 especialistas em direito tributário, entre os quais, representantes do Poder Judiciário, Ministério Público, Universidades, Administração Pública e Advocacia, concluiu que a lei complementar é necessária para definir as condições para gozo das imunidades.

O Ministro Moreira Alves, todavia, deixou claro que não cabe à lei infraconstitucional impor requisitos não constantes da Constituição, cabendo-lhe apenas explicitá-los:

“O problema, aqui, não é saber se é só lei ordinária ou se é só lei complementar ou se é lei ordinária para os requisitos da estrutura da entidade e lei complementar para regular a limitação da competência tributária. Mas aqui é uma quarta posição. Diz: "Aquela lei é apenas a referente aos requisitos

7 Coordenação de Análise de Jurisprudência, D.J. 16/06/2000, Ementário n. 1995-1, Tribunal Pleno, 11/11/1999.

8 "Embora relevante a tese de que, não obstante o $\S 7^{\circ}$ do art. 195 só se refira a 'lei', sendo a imunidade uma limitação constitucional ao poder de tributar, e de se exigir lei complementar para o estabelecimento dos requisitos a ser observados pelas entidades em causa, no caso, porém, dada a relevância das duas teses opostas, e sendo certo que, se concedida a liminar, revigorar-se-ia legislação ordinária anterior que não foi atacada, näo deve ser concedida a liminar pleiteada.

É relevante o fundamento da inconstitucionalidade material sustentada nos autos (o de que os dispositivos ora impugnados - o que não poderia ser feito sequer por lei complementar estabeleceram requisitos que desvirtuam o próprio conceito constitucional de entidades beneficentes de assistência social, bem como limitaram a própria extensāo da imunidade). Existência, também, do 'periculum in mora'.

Referendou-se o despacho que concedeu a liminar para suspender a eficácia dos dispositivos impugnados nesta ação direta" (grifos meus) (Comentários à Const. do Brasil, $6^{\circ}$ vol., tomo I, ed. 2001, ob. cit., p. 205/206). 
para se saber se uma entidade é ou não aquela entidade, que, pela Constituição, goza de imunidade".

Agora, fora daí, em se tratando de matéria que diga respeito a limitação de imunidade, nenhuma lei pode estabelecer estas restrições. Por quê? Porque estas restrições são estritamente aquelas que estão na Constituição" (grifos meus) ${ }^{9}$.

E as conclusões do referido Simpósio Nacional foram as seguintes:

“2) Como deve ser interpretada a cláusula "atendidos os requisitos da lei", constante do art. ISO, VI, c, da CF? Como significativa necessidade de lei complementar, remetendo, pois, ao art. 14 do CTN ou, pelo contrário, de que mera lei ordinária pode fixar os requisitos, extrapassando, inclusive, aqueles fixados pelo CTN?"

Proposta da Comissão de Redação aprovada em Plenário:

\begin{tabular}{lcc} 
& A favor & Contra \\
Comissão 1: & 74 & 6 \\
Comissão 2: & 62 & \\
Comissão 3: & 26 & \\
\cline { 2 - 3 } & 162 & 6
\end{tabular}

A expressão constante do art. 150, VI, c, da CF - "atendidos os requisitos da lei" refere-se àqueles que, necessariamente, devem constar de lei complementar, veículo competente para regular as limitações constitucionais do poder de tributar (CF art. 146, 11, e CTN, art. 14).

Comissão 1:

Decisão por maioria:

- A favor: 74 votos.

- Contra: 6 votos.

Sendo a imunidade tributária uma limitação ao poder de tributar, a cláusula "atendidos os requisitos da lei" constante do art. 150, VI, C, da CF, deve ser interpretada sistematicamente, exigindo-se, por conseqüência, a estrutura exclusiva de lei complementar, em atenção ao disposto no art. 146, 11, da $\mathrm{CF}$ e art. 14 do CTN.

Comissão 2:

- Decisão unânime: 62 votos.

9 Processo Administrativo Tributário, Pesquisas Tributárias - Nova Série 5, 2* ed. atualizada, ed. CEU/Revista dos Tribunais, p. 32/33. 
Os requisitos subjetivos e objetivos para o gozo de imunidade têm que ser instituidos por lei complementar, por força do art. 146, II, da CF.

\section{Comissão 3:}

- Decisão unânime: 26 votos.

A cláusula "atendidos os requisitos da lei", constante do art. 150, inc. VI, alínea $\mathrm{c}$, da $\mathrm{CF} / 88$ deve ser interpretada sistematicamente em consonância com o disposto no art. 146, inc. II, da CF/88, eis que impõe a necessidade de lei complementar para dispor sobre imunidade, que consubstancia limitação constitucional ao poder de tributar e exige uniformidade de critérios. Entende, ainda, a Comissão que a lei complementar vocacionada é o Código Tributário Nacional (art. 14), que foi recepcionado nos termos do $\S 5^{\circ}$ do art. 34 do ADCT da CF/88" ${ }^{10}$.

Não tenho dúvida - em face da ADIN n. 2028, em que o Ministro Moreira Alves sinalizou a relevância da corrente que sustenta a necessidade de lei complementar para veiculação das imunidades e detectou a impossibilidade de termos 5.500 leis ordinárias das três esferas da Federação, cada uma delas regulando, conforme os humores do legislador, as imunidades dos impostos insertos em suas esferas respectivas de competência impositiva - que somente lei complementar pode explicitar o conteúdo da norma constitucional ${ }^{11}$.

Um segundo aspecto de relevância diz respeito ao conceito de entidade beneficente.

Na já mencionada ADIN, S.Exa. o Min. Moreira Alves acompanhado por outros nove ministros, declarou que a entidade filantrópica é espécie do gênero beneficente, que pode acobertar instituições filantrópicas e não filantrópicas - considerando estas até mais úteis, por terem maiores disponibilidades - desde que sem fins lucrativos.

Escreve S.Exa. que:

“Aliás, são essas entidades - que, por não serem exclusivamente filantrópicas, têm melhores condições de atendimento aos carentes a quem o prestam - que devem ter sua criação estimulada para o auxílio ao Estado nesse setor, máxime em época em que, como a atual, são escassas as doações

10 Processo Administrativo Tributário, ob. cit., p. 752/753.

11 O Ministro Moreira Alves admite lei ordinária de conteúdo inócuo ao dizer: "Porque aí é absolutamente inócua a existência ou não daquela lei, porém ela não é inconstitucional, desde que ela tenha interpretado a Constituição de acordo com o que a interpretação mais correta da Constituição leve a concluir. Porque é óbvio. Se vem uma lei ordinária e diz o que a Constituição diz, interpretando bem a Constituição, não se vai declarar inconstitucional aquela lei que disse aquilo que, ainda que ela não dissesse, seria a interpretação decorrente diretamente do texto constitucional" (grifos meus) (Processo Administratrivo Tributário, ob. cit. p. 32). 
para a manutenção das que se dedicam exclusivamente à filantropia" 12 . (grifos meus).

No voto do Min. Moreira Alves, cabe realçar aspecto relevante, qual seja, o de que considerou as entidades sem fins lucrativos não filantrópicas não suscetíveis de sofrerem por parte da lei limitações não existentes na Constituição:

“De outra parte, no tocante às entidades sem fins lucrativos educacionais e de prestação de serviços de saúde que não pratiquem de forma exclusiva e gratuita atendimento a pessoas carentes, a própria extensão da imunidade foi restringida, pois só gozarão desta "na proporção do valor das vagas cedidas integral e gratuitamente a carentes, e do valor do atendimento à saúde de caráter assistencial", o que implica dizer que a imunidade para a qual a Constituição não estabelece limitação em sua extensão o é por lei" ${ }^{13}$, o que considerou inconstitucional.

Um terceiro aspecto mister se faz considerar, ou seja, de que as instituições educacionais são consideradas de assistência social, se forem sem fins lucrativos.

É, ainda, S.Exa. quem esclarece:

"Do exame sistemático da Constituição, verifica-se que a Seção relativa à Assistência Social não é exauriente do que se deve entender como Assistência Social, pois, além de não se referir a carentes em geral, mas apenas a família, crianças, adolescentes, velhos e portadores de deficiência sem sequer exigir de todos estes que sejam carentes, preceitua, em seu art. 203, que ela se fará independentemente de contribuição à seguridade social, a indicar que será gratuita, o que só se compatibilizará com o disposto no $\S$ único do art. 149 - que permite que os Estados, o Distrito Federal e os Municípios instituam contribuição cobrada de seus servidores para o custeio, em benefício destes, de sistemas de previdência e assistência social - se se entender que, para a Constituição, o conceito de assistência social é mais amplo não só do doutrinário, mas também do adotado pelo art. 203 para a disciplina específica prevista nele e no dispositivo que se lhe segue" ${ }^{14}$ (grifos meus),

demonstrando que a interpretação possível do artigo 203 implica sentido mais abrangente da imunidade.

Pessoalmente, considero que, por ser a imunidade uma vedação absoluta ao poder de tributar, sua exegese só pode ser extensiva, visto que, outorgar a faculdade, ao ente tributante - com seus permanentes problemas de caixa - , de definição do

12 ADINs 2028-5 e 2036-6-DF (Medida Liminar), D.J. 16/06/2000, Ementário 1995-1.

13 ADIN 2028-5.

14 ADINs 2028-5 e 2036-6-DF (Medida Liminar), D.J. 16/06/2000, Ementário 1995-1. 
que seria $o$ instituto, poderia transformar, em verdade, o poder regulador, em poder aproveitador, reduzindo o intuito constitucional de permitir que instituições sociais ou educacionais façam o que o governo deveria e não faz com seus tributos.

Em outras palavras, como no passado salientou o Ministro Thompson Flores, no RE n. 80.603-SP:

\section{"PAPEL DE IMPRENSA - ATO INEXISTENTE — INTERPRETAÇÃO LITERAL.}

Não são as dimensões (variáveis segundo o método industrial adotado) que caracterizam o papel para impressão. Ao contrário da isenção tributária, cujas regras se interpretam literalmente, a imunidade tributária admite ampla inteligência" (grifos meus) ${ }^{15}$,

a imunidade tem que ser interpretada extensivamente - como de resto o foi na ADIN 2028 - para evitar a mutilação do desiderato constitucional, de permitir que tais instituições façam pelo país, o que o governo não faz.

Infelizmente, as Universidades Federais, apesar de receberem $18 \%$ de impostos federais (artigo 212 da C.F.) arrecadados e agregarem apenas cerca de $30 \%$ do alunado, estão quase sempre em crise.

O certo é que a imunidade tributária, constantemente, tem recebido interpretação extensiva - e sempre quando se faz necessária - para atalhar a ânsia e voracidade dos fiscos. No caso das instituições de ensino, foi reconhecida por S.Exa., o Min. Moreira Alves e mais nove ministros, ao dar uma inteligência abrangente do art. 203 da C.F., conforme transcrição anterior ${ }^{16}$.

Um quarto aspecto é de se considerar.

$\mathrm{O}$ artigo $213 \mathrm{da}$ C.F. declara que:

“Os recursos públicos serão destinados às escolas públicas, podendo ser dirigidos a escolas comunitárias, confessionais ou filantrópicas, definidas em lei, que: I. comprovem finalidade não-lucrativa e apliquem seus excedentes financeiros em educação; II. assegurem a destinação de seu patrimônio a outra escola comunitária, filantrópica ou confessional, ou ao Poder Público, no caso de encerramento de suas atividades" 17 .

15 DJU de 24/5/79, p. 4090.

16 Na linha de interpretação extensiva da imunidade, leia-se o seguinte acórdão: "Revista Médica - anúncios nela inseridos - imunidade.

Despacho (negando) indeferindo o RE (indeferindo o Agravo para subida do RE), interposto pela PMSP, e confirmando o entendimento de que a imunidade constitucional abrange não só a revista, como periódico, como também, os anúncios ou publicidade. Citados nesse sentido, dois acórdãos do Pleno do STF: RE n. 77.867 (RR), na RTJ 72.189; RE-87.049-SP, na RTJ 87-608/612. O despacho é do Min. Oscar Corrêa, DJU de 16/11/82, p. 11.577".

17 Celso Ribeiro Bastos refere-se exclusivamente a "recursos públicos" colocados, isto é, disponibilizados, não cuidando da denominada "renúncia fiscal" que não existe nas imunidades, por serem estas vedações ao poder de tributar. Escreveu: "Fica estabelecido, de acordo com o preceito 
Ora, o requisito I, alargado, encontra-se no artigo 14 do CTN, cuja redação repito:

\begin{abstract}
"O disposto na alínea "c" do inc. IV do art. $9^{\circ}$ é subordinado à observância dos seguintes requisitos pelas entidades nele referidas: I. não distribuírem qualquer parcela de seu patrimônio ou de suas rendas, a título de lucro ou participação no seu resultado; II. aplicarem integralmente, no país, os seus recursos na manutenção dos seus objetivos institucionais; III. manterem escrituração de suas receitas e despesas em livros revestidos de formalidades capazes de assegurar sua exatidão.
\end{abstract}

Abrangendo, pois, até mais do que a Constituição exige.

São, de resto, os únicos requisitos possíveis para que o Brasil tenha sua regulação das limitações ao poder de tributar, fundamentada em uma única concepção de imunidade e de condições, e não 5.500 , como seria o caso, se fosse a lei ordinária, e não a complementar, a explicitar a Constituição.

Quanto ao inciso II, quase todas as instituições sem fins lucrativos, filantrópicas ou não, têm o dispositivo colocado em seus estatutos.

Ora, o que o art. 213 está determinando, é que as instituições de educação imunes por força dos artigos 150 , inc. VI, letra "e", e $195, \S 7^{\circ}$, filantrópicas ou não, desde que sejam sem fins lucrativos e preencham os requisitos dos seus incisos I e II, não só gozam de imunidades, como podem receber recursos públicos.

De qualquer forma, o art. 213, em nenhum momento, cuida de imunidades, sendo, portanto, imprestável para sustentar argumentação no sentido de que $a \mathrm{imu}$ nidade é um recurso público colocado nas escolas.

E, aqui, já cuido do quinto ponto preambular.

Que é uma imunidade tributária? É a vedação absoluta ao poder de tributar. Ao Poder Público está interditado entrar em determinadas áreas para tributá-las. Não há que se falar em renúncia fiscal, nas imunidades, visto que nada se pode tributar em relação a estas situações, pessoas ou bens, constitucionalmente protegidos da imposição fiscal. Não há, portanto, renúncia a nada e se não está renunciando a nada, não está versando "recursos públicos" decorrentes da imunidade, nas instituições mencionadas no art. $213^{18}$.

contido no art. 213 da Constituição, que a prioridade de distribuição dos recursos públicos deve recair precipuamente sobre as escolas públicas. Contudo, existe a possibilidade de se destinarem os recursos públicos às escolas comunitárias, confessionais ou filantrópicas, definidas por lei. Esse benefício não será concedido aleatoriamente, mas sim de acordo com a determinação e o entendimento de lei infraconstitucional. Para receber os benefícios, os estabelecimentos de ensino deverão preencher os requisitos contidos nos incs. I e II do art. 213 da Constituição.

Cumpre dizer que um dos objetivos do dispositivo constitucional sob comento é impedir que os recursos públicos sejam destinados a entidades de ensino com finalidade lucrativa" (grifos meus) (Comentários à Constituição do Brasil, $8^{\circ}$ vol., Ed. Saraiva, 2000, p. 734).

18 O Ministro José Delgado ensina: “A imunidade tributária é uma vedação constitucional à competência tributária. Por essa razão, Amílcar Araújo Falcão a concebeu como sendo: 
O artigo 213 cuida, portanto, de recursos efetivos, e não de "renúncias" ao que não existe, ao que o Poder Público não tem, à proibição do "direito de tributar".

Em palavras definitivas, não pode o Poder Público considerar a imunidade uma renúncia fiscal, visto que não pode renunciar àquilo que nunca teve e nunca terá, visto que as imunidades são cláusulas pétreas da lei maior.

Com efeito, nem lei ordinária, nem lei complementar, nem emenda constitucional podem alterar as imunidades tributárias, por serem cláusulas pétreas, por força do art. $60, \S 4^{\circ}$, inc. IV da C.F.:

“ $\S 4^{\circ}$ Não será objeto de deliberação a proposta de emenda tendente a abolir: ... IV. os direitos e garantias individuais" ${ }^{19}$.

“... forma qualificada ou especial de não incidência por supressão, na Constituição, de competência impositiva ou do poder de tributar, quando se configuram certos pressupostos, situações ou circunstâncias previstas pelo estatuto supremo", acrescentando a seguir: "A interpretação do seu alcance há de se voltar para não enfrentá-la como sendo um favor ou uma renúncia fiscal. A sua atuação tem força de limitar o poder de tributar, considerando-se a necessidade de preservaçāo de determinados valores tidos como indispensáveis e relevantes para a sociedade. Há, portanto, uma razão principiológica de maior alcance presente em qualquer espécie de imunidade que se vincula ao valor que visa a proteger. Imunidade é obstáculo criado por disposiçāo constitucional, resultando na não incidência de qualquer lei ordinária que visa a tributar determinado fato econômico ou financeiro" (grifos meus) (Imunidades Tributárias, Pesquisas Tributárias Nova Série 4, ob. cit. p. 54/55).

19 Escrevi: "Os direitos e garantias individuais conformam uma norma pétrea. Não são eles apenas os que estão no artigo $5^{\circ}$, mas, como determina o $\S 2^{\circ}$ do mesmo artigo, incluem outros que se espalham pelo texto constitucional e outros que decorrem de uma implicitude inequívoca. Trata-se, portanto, de um elenco cuja extensão não se encontra em textos constitucionais anteriores.

Em posição diversa, entendo que os direitos e garantias individuais são aqueles direitos fundamentais plasmados no texto constitucional - e apenas nele - afastando-se, de um lado, da implicitude dos direitos não expressos ou de veiculação infraconstitucional, assim como restringindo, por outro lado, aqueles direitos que são assim considerados pelo próprio texto e exclusivamente por ele. Os direitos e garantias individuais conformam uma norma pétrea. Não são eles apenas os que estão no artigo $5^{\circ}$, mas, como determina o $\S 2^{\circ}$ do mesmo artigo, incluem outros que se espalham pelo texto constitucional e outros que decorrem de uma implicitude inequívoca. Trata-se, portanto, de um elenco cuja extensão não se encontra em textos constitucionais anteriores.

Assim sendo, o artigo 150 faz expressa menção a direitos e garantias individuais, como tais conformados no capítulo do sistema tributário. Tal conformação, à evidência, oferta, por este prisma, a certeza de que está ela no elenco complementar do artigo 150 e, por outro, que é tido pelo constituinte como fundamental.

Por tal perfil, apenas os direitos e garantias individuais expressamente expostos no artigo da Constituição seriam cláusulas pétreas.

O Supremo Tribunal Federal parece ter hospedado tal exegese no momento em que não acatou como cláusula pétrea o direito individual do contribuinte a estar assegurado por um sistema tributário inelástico, com a válvula de escape decorrente da competência residual da União, visto que não era expressa a cláusula.

Na ocasião, a E.C. $n^{\circ} 3 / 93$, entretanto, foi tisnada por aqueles que defendiam que os direitos individuais não seriam cláusulas pétreas, pois o S.T.F. acatou as cláusulas expressas.

Assegurou, pois, o Pretório Excelso, os contribuintes, ao reconhecer a prevalência do explícito princípio da anterioridade, ou seja, o direito de não ser tributado no mesmo exercício, apesar de 
E para a constatação de que as imunidades são cláusulas pétreas, basta atentar para o caput do art. 150 da C.F., que diz:

"Art. 150. Sem prejuizo de outras garantias asseguradas ao contribuinte, é vedado à União, aos Estados, ao Distrito Federal e aos Municípios:

I - exigir ou aumentar tributo sem lei que o estabeleça;

II - instituir tratamento desigual entre contribuintes que se encontrem em situação equivalente, proibida qualquer distinção em razão de ocupação profissional ou função por eles exercida, independentemente da denominação jurídica dos rendimentos, títulos ou direitos;

III - cobrar tributos:

a) em relação a fatos geradores ocorridos antes do início da vigência da lei que os houver instituído ou aumentado;

b) no mesmo exercício financeiro em que haja sido publicada a lei que os instituiu ou aumentou;

IV - utilizar tributo com efeito de confisco;

$\mathrm{V}$ - estabelecer limitações ao tráfego de pessoas ou bens, por meio de tributos interestaduais ou intermunicipais, ressalvada a cobrança de pedágio pela utilização de vias conservadas pelo Poder Público;

$V I$ - instituir impostos sobre:

a) patrimônio, renda ou serviços, uns dos outros;

b) templos de qualquer culto;

c) patrimônio, renda ou serviços dos partidos políticos, inclusive suas fundações, das entidades sindicais dos trabalhadores, das instituições de educação e de assistência social, sem fins lucrativos, atendidos os requisitos da lei;

d) livros, jornais, periódicos e o papel destinado à sua impressão", (grifos meus)

sendo, seu inciso VI, totalmente dedicado às imunidades.

a exigência ser decorrente de emenda constitucional. Não estendeu, todavia, esse reconhecimento ao princípio implícito de não ser incidido por nenhum outro tributo que não aquele da competência residual, por decorrente do princípio do "sistema fechado e inelástico".

Tal sinalização do S.T.F., à nitidez, facilitou a conformação mais nítida dos limites da petrificação normativa no concernente aos direitos e garantias individuais.

Como se percebe, a Suprema Corte sinalizou os limites das garantias e direitos individuais, estabelecendo que a Constituição Federal, para cada direito, assegurou o exercício de uma tutela, isto é, há uma garantia para cada direito elencado na lei maior.

Desta forma, direitos e garantias individuais explícitos, no texto supremo, são imodificáveis por emenda" (Comentários à Constituição do Brasil, $4^{\circ}$ vol., tomo I, Ed. Saraiva, $3^{a}$ ed., 2002, p. $417 / 420)$. 
O que diz o art. 150 caput é que, além de todas as garantias expostas nele, há outras asseguradas na Constituição. As imunidades, entretanto, estão expressamente contempladas.

Um sexto ponto merece consideração e diz respeito à autonomia das Universidades.

O art. 207 da Constituição Federal declara que são autônomas as Universidades, estando assim redigido:

"As Universidades gozam de autonomia didático-científica, administrativa $e$ de gestão financeira e patrimonial, e obedecerão ao princípio de indissociabilidade entre ensino, pesquisa e extensão" (grifos meus).

Não há condicionamento a esta autonomia, nem pode haver restrição legal a turvar a eficácia dessa autonomia.

Se a lei ordinária ou complementar pretender reduzir a ampla autonomia que a Constituição assegura, será uma lei complementar ou ordinária inconstitucional.

É interessante que o art. 207 não condiciona a autonomia aos termos da lei, mas apenas declara que as Universidades e os institutos de pesquisas são autônomos e, neste particular, a lei não pode reduzi-la ${ }^{20}$.

Um sétimo ponto merece consideração, a saber: o art. 209 da C.F. só impõe ao ensino privado duas condições, ou seja, cumprir as normas gerais de educação, que não podem ser restritivas, e ser avaliado pelo Poder Público.

Está assim redigido:

"O ensino é livre à iniciativa privada, atendidas as seguintes condições: I. cumprimento das normas gerais da educação nacional; II. autorização e avaliação de qualidade pelo Poder Público" 21 .

20 Manoel Gonçalves Ferreira Filho esclarece: "Autonomia. O termo evidentemente não é empregado no seu sentido etmológico, grego, de "independência", mas sim no de autodeterminação dentro de limites traçados por norma superior. É a lição de Mortati (Istituzioni di diritto pubblico, Pádua, CEDAM, 1967, v. 2, p. 694): "Poder de autodeterminação exercitável de modo independente mas nos limites consentidos pela lei estatal superior".

Claro está, portanto, que é a lei, no caso a lei de "diretrizes e bases da educação nacional" (v., supra, art. 22, XXIV), que vai definir a extensão desse poder de autodeterminação. Entretanto, nāo poderá negá-la, numa medida mínima que seja, quanto às matérias anunciadas neste artigo: didático-científica, administrativa e de gestão financeira e patrimonial" (grifos meus) (Comentários à Constituição Brasileira de 1988, vol. 2, Ed. Saraiva, 2a ed., 1999, p. 246).

21 A eminente vice-presidente do Tribunal Regional Federal da $3^{\mathrm{a}}$ Região, Professora e Desembargadora Diva Malerbi, declara que para gozo da imunidade do art. 150, VI, inciso " $c$ ", da C.F.: "Esta cláusula 'atendidos os requisitos da lei"”, constante do art. 150, VI, c, da Constituição Federal deve assim ser interpretada:

[1] É de observância obrigatória pelos partidos políticos e suas fundações, entidades sindicais dos trabalhadores e pelas instituições de educação e de assistência social.

[2] Tal lei, pela interpretação sistemática da Constituição, só pode ser a lei complementar (CF, art. 146, II). Toda imunidade é uma limitação do poder de tributar. Estas, no sistema da Constituição atual, só podem ser reguladas por lei complementar. 
Ora, preenchidas as duas referidas condições, a Universidade privada, constitucionalmente, deve ter autonomia nos termos do art. 207 e se for beneficente (filantrópica ou não filantrópica sem fins lucrativos), não pode sofrer qualquer restrição não existente ou admitida pela Constituição.

Um oitavo aspecto há de ser considerado.

$\mathrm{O}$ artigo $170, \S$ único, da C.F. declara que:

"É assegurado a todos o livre exercício de qualquer atividade econômica, independentemente de autorização de órgãos públicos, salvo nos casos previstos em lei",

mostrando que não pode haver restrição - e a Constituição não a impõe, no capítulo da educação - às instituições universitárias, desde que preencham exclusivamente a lei de diretrizes e bases, devendo ser reconhecidas e não obstaculizadas ${ }^{22}$.

Qualquer restrição que implique limitar sua atuação, passando a ter que responder por ações próprias do ensino público universitário, é manifestamente inconstitucional.

É de se lembrar que, obedecidas as condições constitucionais dos arts. 207, 209, 213 da lei suprema, as instituições sem fins lucrativos (filantrópicas ou não) não podem ser impedidas de atuar, em virtude de restrições não constitucionais.

O dispositivo está, de resto, vinculado ao disposto no artigo 174, caput, segundo o qual, quanto à iniciativa privada, o planejamento econômico é meramente indicativo, estando assim redigido:

[3] Tal lei complementar não é lei federal, mas nacional, de observância obrigatória por parte da União, Estados, Distrito Federal e Municípios.

[4] Tal lei complementar, na espécie, ocupa-se tão-somente em explicitar as medidas aptas a assegurar a eficácia jurídica do comando contido no art. 150, VI, c, da Constituição Federal. Só o constituinte pode definir os limites em que deve ser exercido o poder tributário (Imunidades) e só a lei complementar da Constituiçāo Federal pode regulála. Mas não lhe é dado anular ou restringir a eficácia do comando constitucional.

[5] Faz as vezes da lei complementar pedida pela Constituição, na espécie, o art. 14 do Código Tributário Nacional (Lei 5.172/66), assim recepcionado na ordem constitucional que se the seguiu.

[6] De acordo com o art. 14 do Código Tributário Nacional, só gozarão de imunidade: [a] se não tiverem fins lucrativos; [b] se aplicarem todos os seus recursos no País; [c] se escriturarem suas receitas em livros próprios e de modo hábil a permitir a verificação de sua exatidão" (Imunidades Tributárias, Pesquisas Tributárias - Nova Série 4, ed. CEU/Revista dos Tribunais, 1998, p. 73).

22 José Cretella Jr. lembra que: "Não se trata de trabalho, ofício ou profissão, exercícios assegurados pelo art. $5^{\circ}$, XIII, da Constituição, mas de exercício de atividade econômica, industrial, comercial ou artesanal, não proibido, aliás, desde 1824, quando a Constituição do Império, art. 179, prescreveu: "Nenhum gênero de indústria ou comércio pode ser proibido". O exercício de atividade econômica é permitido, independentemente de autorização de órgão público, salvo nos casos previstos em lei" (Comentários à Constituição 1988, VIII, Forense Universitária, 1993, p. 3987). 
"Como agente normativo e regulador da atividade econômica, o Estado exercerá, na forma da lei, as funções de fiscalização, incentivo e planejamento, sendo este determinante para o setor público e indicativo para o setor privado". (grifos meus)

Ora, qualquer planejamento econômico oficial que imponha ônus ao segmento privado é inaceitável, principalmente se a não adesão ao planejamento econômico meramente indicativo acarretar sanções ao que não desejar nele ser incluído ${ }^{23}$.

Em outras palavras, sendo livre à iniciativa privada o ensino universitário, desde que respeitados os parâmetros dos artigos 209 e 213, quando se trata de instituições filantrópicas, à evidência, aplica-se a tais instituições os arts. 170, § único, e 174 da Carta Maior, que impedem o planejamento econômico obrigatório, para o segmento privado - o que, no caso das instituições universitárias privadas, ocorreria com o PROUNI, ao condicionar a sua não adesão a determinadas sanções.

Um nono aspecto é de ser considerado. E é elementar. Imunidade não se confunde com isenção.

Embora seja sempre desagradável a autocitação, mas por questão de facilidade, em face da urgência requerida, explico, de forma didática, a diferença entre isenção, não-incidência e imunidade, transcrevendo trecho do livro Direito Empresarial:

"A imunidade é o mais relevante dos institutos desonerativos. Corresponde vedação total ao poder de tributar. A imunidade cria área colocada, constitucionalmente, fora do alcance impositivo, por intenção do constituinte, área necessariamente de salvaguarda absoluta para os contribuintes nela hospedados. A relevância é de tal ordem que a jurisprudência tem entendido ser impossível a adoção de interpretação restritiva a seus comandos legais sendo, obrigatoriamente, a exegese de seus dispositivos ampla.

23 Miguel Reale esclarece: "Vem, a seguir, o art. 174, que tem sido o cavalo de batalha dos que persistem em proclamar a natureza intervencionista do Estatuto Político de 1988. Nada melhor do que a reprodução desse preceito: "Como agente normativo e regulador da atividade econômica, o Estado exercerá na forma da lei (note-se) as funçōes de fiscalização, incentivo e planejamento, sendo este determinante para o setor público e indicativo para o setor privado" (grifei).

Em face de um texto tão claro, custa-me crer que se possa pensar em dirigismo econômico, cuja característica principal é a natureza imperativa e não meramente indicativa do planejamento para os particulares, considerados individualmente ou consorciados em empresas.

Dir-se-á que o Estado é configurado como "Agente normativo e regulador" da economia, mas, a esta altura da evolução histórica, a afirmação contrária daria provas de preocupante irrealismo. O importante é que se declare, tal como consta do mencionado art. 174 que, naquela qualidade, o Estado deverá exercer suas funções de fiscalização e planejamento "na forma da lei". Mais uma vez o princípio da legalidade baliza a ação estatal e de modo puramente indicativo.

Praticam, pois, um grande erro aqueles que não contribuem com uma interpretação objetiva e serena do texto constitucional, assumindo atitude hostil ou depreciativa perante o Estatuto de 1988, o qual, apesar das múltiplas contradições que o comprometem, abre clareiras à defesa tão necessária da livre iniciativa, o que quer dizer, da economia de mercado" (grifos meus) (Aplicações da Constituição de 1988, Ed. Forense, 1990, p. 15). 
Compreende-se o desenho pretoriano, visto que os crônicos déficits públicos, cujo mérito não nos cabe examinar na área específica do direito tributário, eis que de reflexo jurídico apenas no campo do direito financeiro e econômico, terminam por gerar tentaçōes ao poder tributante de reduzir o espectro de atuação da norma vedatória. A fim de fulminar tais conveniências exegéticas, o Supremo tem, reiteradamente, insistido que a imunidade só se pode interpretar extensivamente. A publicidade obtida pelos próprios jornais, apesar de não constar expressamente do art. 19, inc. III, letra "d" da E.C. n. 1/69 nele foi incluída por força de decisões da mais alta Corte.

$\mathrm{Na}$ imunidade, não há nem o nascimento da obrigação fiscal, nem do conseqüente crédito, em face de sua substância fática estar colocada fora do campo de atuação dos poderes tributantes, por imposição constitucional. Independe, portanto, das vontades legislativas das competências outorgadas pela lei maior.

A não-incidência, materialmente, se reveste da mesma estrutura. Não há nem nascimento da obrigação tributária, nem do crédito respectivo, em face de que as pessoas ou situações postas fora da imposição não geram, por seus atos ou ocorrências fáticas, nem obrigação, nos termos dos arts. 113 e 114 do CTN, nem crédito correspondente (arts. 139 e 142), que é o ingresso para o universo administrativo, em nível de conhecimento e ação, do vinculado fato gerador.

A diferença reside, todavia, na origem do instituto. Na hipótese de não-incidência impede-se o surgimento da obrigação e do crédito, porque o Poder tributante, que pode, não deseja poder. Tem a faculdade constitucional de impor, mas abdica do exercício de sua capacidade. Na imunidade, o Poder tributante não tem qualquer poder. Não abdica do exercício de nenhum direito, porque não tem nenhum direito à imposição.

Na não-incidência, o Poder tributante poderá preencher a área não acobertada por sua ação, sempre que o desejar, através de atos oriundos de suas casas legislativas, direta ou indiretamente.

Desta forma, a não-incidência se constitui no abandono do exercício da competência impositiva, não por falta de capacidade, mas por ato de príncipe, enquanto na imunidade tal exercício está definitivamente proibido. A não-incidência cria área provisória de afastamento da obrigação tributária, enquanto a imunidade, área definitiva.

Embora com consequiências semelhantes, no concernente aos efeitos sobre o sujeito passivo da relação tributária, a isenção difere das duas outras figuras legislativas. É que na isenção nasce a obrigação tributária, sendo apenas excluido o crédito correspondente.

Tal colocação decorre do art. 175 do CTN, assim redigido:

"Art. 175. Excluem o crédito tributário: I. a isenção; II. a anistia.

$\S$ único. A exclusão do crédito tributário não dispensa o cumprimento das obrigações acessórias dependentes da obrigação principal cujo crédito seja excluído, ou dela conseqüentes". 
O STF adotou a interpretação acima (nascimento da obrigação tributária e eliminação do crédito), a partir dos polêmicos casos de créditos escriturais de ICM nas importações de matérias-primas antes da E.C. 23/83. Negou, por outro lado, direito ao mesmo nas hipóteses de diferimento da incidência. É que, no primeiro caso, a hipótese configurava-se como de isenção (nascimento da obrigação tributária e exclusão do crédito), razão pela qual a obrigação nascida gerava direito a crédito escritural, que não se confunde com crédito tributário.

No segundo, a hipótese ganhava a tonalidade de não-incidência, com o que a inexistência de nascimento da obrigação tributária acarretava o afastamento de pretenso direito a crédito escritural, inviável por força da não-incidência.

Desta forma, na isenção nasce a obrigação tributária, não nascendo o crédito tributário, vale dizer, a obrigação tributária existe, mas o Poder Tributante concede o favor ao contribuinte de não convertê-la em crédito tributário ${ }^{24}$.

O que o governo não pode é confundir a imunidade - que é uma vedação absoluta ao poder de tributar, ou seja, área interditada à ação impositiva do Fisco - com isenção, que os governos podem conceder — e aí é concessão — em face de determinados preceitos de interesse da comunidade, e com "não-incidência", que corresponde ao não-exercício do poder impositivo ${ }^{25}$.

No que diz respeito às entidades imunes de educação, não se trata de entidades isentas, visto que não é a lei ordinária que outorga a isenção, mas sim a Constituição que proíbe a tributação.

E um último ponto de extrema relevância diz respeito ao princípio da igualdade.

A Constituição proíbe que brasileiros sejam tratados desigualmente. $\mathrm{O}$ aluno universitário, seja ele qual for, deve ter os mesmos direitos, não podendo a lei discriminar dizendo que as minorias têm mais direitos que as maiorias, inclusive o direito de ingressar com menor qualificação técnica, nas universidades públicas e privadas.

Estou convencido de que por força do art. $3^{\circ}$, inciso IV, da Constituição, assim redigido:

24 Direito Empresarial - Pareceres, $2^{a}$ ed., Forense, 1986, p. 298 a 302.

25 Escrevi: "Esta é a razão pela qual a interpretação das isenções é literal (leia-se restritiva), nos termos do art. 111 do CTN, assim redigido: "Art. 111. Interpreta-se literalmente a legislação tributária que disponha sobre: I. suspensão ou exclusão do crédito tributário; II. outorga de isenção; III. dispensa do cumprimento de obrigaçōes tributárias acessórias".

O poder que concede o favor é aquele com o direito a explicitar os limites da concessão, por sua casa legislativa, desde que não retirando o estímulo concedido por interpretações não restritivas, mas mutiladoras. Quem dá tem o direito de dizer como deu, mas não de dizer que não deu" (Direito Empresarial - Pareceres, ob. cit., p. 303). 
"Constituem objetivos fundamentais da República Federativa do Brasil: ... IV. promover o bem de todos, sem preconceitos de origem, raça, sexo, cor, idade e quaisquer outras formas de discriminação".

não pode haver discriminação de qualquer natureza. Em outras palavras, o branco não pode ser discriminado em relação ao preto, por ser branco, risco de se ferir o art. $3^{\circ}$ da C.F. É de se lembrar que o constituinte usa expressão de indiscutível densidade, ao dizer "quaisquer outras formas de discriminação", além das enunciadas $^{26}$.

Entendo que as políticas públicas, os recursos públicos — nas imunidades não há recursos públicos — podem ser direcionados às minorias, através de ações afirmativas. O que não pode haver é discriminação das maiorias, por força de uma concepção errônea do princípio da igualdade e "da não-discriminação", que leva o branco a ser um cidadão inferior ao negro, em face de estes estarem privilegiados por técnicas e qualificações a que aqueles não têm acesso.

Enfim, não pode a lei ordinária criar qualquer discriminação, em relação a todas as imunidades, até porque, por força do caput do artigo $5^{\circ}$ da C.F., assim redigido:

"Todos são iguais perante a lei, sem distinção de qualquer natureza, garantindo-se aos brasileiros e aos estrangeiros residentes no país a inviolabilidade do direito à vida, à liberdade, à igualdade, à segurança e à propriedade, nos termos seguintes: ...". (grifos meus)

No Brasil, todos são iguais perante a lei, não podendo ser discriminados, por preconceitos ou ideologias, alguns cidadãos em relação aos outros ${ }^{27}$.

26 Manoel de Oliveira Franco Sobrinho, ao comentar o dispositivo, lembra que a lei deverá exigir o cumprimento destas "não discriminações", o que decididamente não ocorre com o PROUNI que cria discriminaçōes. Declara: "Na existência efetiva da regra jurídica que há de fazer cumprir os objetivos fundamentais do Estado, temos de atender no tempo em que ela se elabora e faz viva, no momento em que passa. a incidir sobre fatos assegurando a si mesma capacidade (força) para ministrar mudanças e novas relações.

"Promover o bem de todos, sem preconceitos de origem, raça, sexo, cor, idade e outras formas de discriminação", conduz o hermeneuta ao conhecimento (art. $6^{\circ}$ ) do que asseguram" aos brasileiros e estrangeiros residentes no país os direitos concernentes à vida, à liberdade, à segurança $\mathrm{e}$ à propriedade".

Os pressupostos objetivos de fundo, levados em termos políticos à problemática geo-social, darão ao Estado motivos ou concedem ao Estado poder ou razões de ordem jurídica para pedir leis que supram adequadamente normas constitucionais nas esferas de competência federal, estadual e municipal" (Comentários à Constituiçāo, $1^{\circ}$ vol., Biblioteca Jurídica Freitas Bastos, 1990, p. 144). 27 Pinto Ferreira lembra que: "IGUALDADE — O princípio da igualdade é norma constitucional básica, chamada também de princípio da isonomia, consistindo na igualdade jurídico-formal de todos diante da lei. O seu objetivo é extinguir privilégios (RDA, 55:144).

Tal princípio deve ser apreciado como uma dupla perspectiva: igualdade na lei e igualdade perante a lei, esta pressupondo a lei elaborada.

O direito grego possuía dois princípios: o da isonomia (igualdade perante a lei) e o de eunomia (o de respeito à lei), como conceitos compatíveis e que se opunham à tirania. 
E no ensino universitário, principalmente, visto que as ações afirmativas deveriam levar o Estado a dar ensino básico de igual qualidade às minorias despreparadas, e não pretender que, no ensino universitário, se outorguem privilégios não técnicos ou em decorrência da má qualificação, àqueles a quem o Estado negou-se a dar, no ensino básico, a qualificação necessária.

Não se constrói um prédio sem alicerces. Um prédio de três andares não se começa a construir pelo $3^{\circ}$ andar, mas pelas fundações.

Todo o projeto que pretende nivelar, no ensino universitário, o que o governo se omitiu em fazer, no ensino básico, é discriminatório e desisonômico, não merecendo, pois, a albergagem da Constituição.

$\mathrm{E}$, à evidência, proibir que determinados cidadãos tenham acesso a financiamento para cursar universidades privadas, a não ser que cursem as Universidades que o governo escolha - o que implica planejamento obrigatório para o setor privado, que é inconstitucional - é forma não só discriminatória, como fere fantasticamente o, princípio da igualdade ${ }^{28}$.

Em face dos 10 pressupostos atrás examinados, tenho entendido, em pareceres, conferências, artigos e escritos que todos os projetos de lei ou leis - há no Rio de Janeiro lei estadual impondo ações afirmativas - que buscam turvar a clareza da distinção entre imunidade e isenção, ou criar discriminações e desigualdades inexistentes na Constituição, são inconstitucionais, merecendo, pois, a matéria melhor reflexão de todos os operadores do direito tributário, nas Universidades, Magistratura, Advocacia, Ministério Público e Administração Oficial.

A sintese do texto constitucional abrange qualquer diferença de tratamento advinda do Legislativo, do Executivo e do Judiciário por motivo de raça, nascimento, classe social, riqueza, sexo etc.

$\mathrm{O}$ princípio da igualdade aplica-se às pessoas naturais, tutelando ainda as pessoas jurídicas, exceto disposição constitucional expressa" (grifos meus) (Comentários à Constituição Brasileira, $1^{\circ}$ vol., Ed. Saraiva, 1989, p. 62).

28 Celso Bastos esclarece: "IV. "Promover o bem de todos sem preconceito de origem, raça, sexo, cor, idade e outras formas de discriminação."

Neste inciso consagra-se formalmente a igualdade. Trata-se, mais uma vez, de colocar sob a modalidade de um objetivo prático o que vem enunciado de forma principiológica na Constituição.

$\mathrm{O}$ art. $5^{\circ}$ da Constituição categoricamente afirma: "Todos são iguais perante a lei, sem distinção de qualquer natureza".

É óbvio que o art. $5^{\circ}$ já encerrava em si mesmo, no caráter enxuto da sua redação, todas as significações inseridas no inciso sob comentário. É claro que diante da igualdade de todos perante a lei não há lugar para o preconceito de origem, de raça, sexo, cor, idade etc." (grifos meus) (Comentários à Constituição do Brasil, $1^{\circ}$ vol., Ed. Saraiva, 2001, p. 493). 


\section{Tratado de Direito Constitucional Financeiro e Tributário}

\section{Os Direitos Humanos e a Tributação - vol. III}

Imunidades e Isonomia

Ricardo Lobo Torres

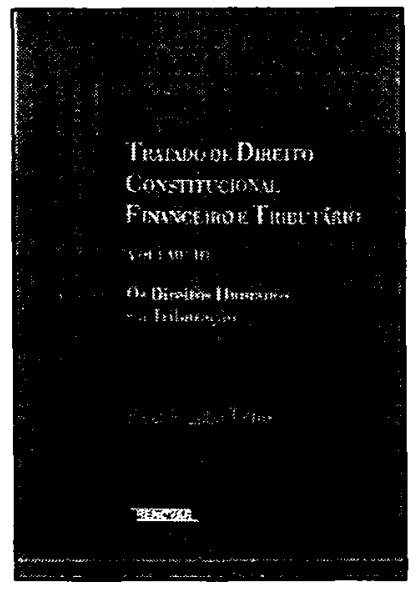

São vistos alguns dos aspectos mais relevantes das limitaçōes constitucionais ao poder de tributar. Rediscute-se o problema da proteção da liberdade fiscal sintetizada nas imunidades a tributos e a impostos que encontram nos direitos humanos o seu fundamento ético e jurídico. Dedica a obra alguns capítulos ao tema da isonomia, que vem recuperando a sua importância após a promulgação da CF de 1988, na qual aparece, sob a forma de proibição de desigualdade, isto é, arbitrariedade, excesso ou desproporção que tornam odiosos os privilégios e as discriminações fiscais.

Ref. 0093

Form. $16 \times 23$
Encadernado

1999
590 págs. $2^{\mathbf{a}}$ ed.

\section{8-1998: Uma Década de Constituição}

\section{Org. Margarida Maria Lacombe Camargo}

Este livro configura um debate interdisciplinar que comporta o direito, e para o qual concorreram vários autores de prestígio nacional e internacional. Nomes que representam o pensamentojuridico brasileiro e que efetivamente contribuem para o aprimoramento de nossas instituições. Temos certeza de que a difusão que agora se faz contribuirá muito para o enriquecimento do debate nacional e para a formaçāo dos novos juristas.

Ref. 0222

Form. 16x23
Brochura 1999
443 págs.

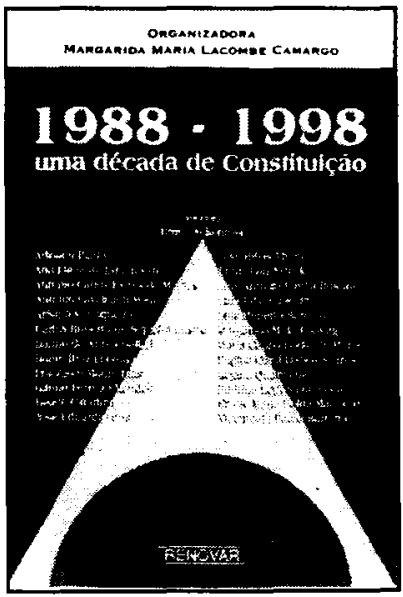

